\title{
Reduced disease severity following therapeutic treatment with Angiotensin 1-7 in a mouse model of Multiple Sclerosis.
}

Lund, B. T. ${ }^{1}$, Stone, R. ${ }^{2 \S}$, Levy, A. M. ${ }^{1}$, Lee, S. ${ }^{1}$, Amundson, E. ${ }^{1}$, Kashani, N. ${ }^{1}$, Rodgers, K. E. ${ }^{3,4}$ and Kelland, E. E. ${ }^{*}$

${ }^{1}$ Department of Neurology, Keck School of Medicine, University of Southern California, Los Angeles, California, USA.

${ }^{2}$ School of Pharmacy Graduate Program, University of Southern California, Los Angeles, California, USA. ${ }^{\S}$ Current Position: Clinical Staff Pharmacist, Multiple Sclerosis, Keck Medicine of USC Specialty Pharmacy, University of Southern California, Los Angeles, California, USA.

${ }^{3}$ Titus Family Department of Clinical Pharmacy, School of Pharmacy, University of Southern California, Los Angeles, California, USA.

${ }^{4}$ Department of Pharmacology, College of Medicine, Center for Innovation in Brain Sciences, The University of Arizona Health Sciences, Tucson, Arizona, USA

* Corresponding author:

University of Southern California

Keck School of Medicine

Dept. of Neurology

1333 San Pablo St

Los Angeles

California, USA. 90033

Tel: +1 3234423036

Email: kelland@usc.edu 


\begin{abstract}
:
Multiple Sclerosis (MS) is a chronic disease of the central nervous system (CNS) characterized by autoimmune and neurodegenerative pathologies for which there is no cure and no defined etiology. Although several, modestly effective, disease modifying drugs are available to treat MS, there are presently no treatments that offer neuroprotection and prevent clinical progression. Therapies are needed that control immune homeostasis, prevent disease progression, and stimulate regeneration in the CNS. Components of the renin-angiotensin-system (RAS) have recently been identified as chemical mediators in the CNS and in neurological disease.

Here we show the beneficial effect of therapeutic treatment with the Mas receptor agonist and metabolite of the protective arm of RAS, angiotensin 1-7 (A(1-7)), in the experimental autoimmune encephalomyelitis (EAE) animal model of MS. Therapeutic treatment with A(1-7) caused a dose-dependent reduction both in clinical disease severity and progression, and was dependent on Mas receptor activation. Further analysis of the most optimal dose of A(1-7) treatment revealed that the reductions in clinical disease course were associated with decreased immune infiltration and demyelination, axonal loss and oxidative stress in the spinal cord. In addition A(1-7) treatment was also associated with increases in circulating alternatively activated monocytes/macrophages.
\end{abstract}

\title{
Key Words:
}

Experimental autoimmune encephalomyelitis; Multiple Sclerosis; Angiotensin 1-7; Immune Infiltration; Demyelination; Axonal damage; Oxidative Stress. 


\section{Introduction:}

Multiple Sclerosis (MS) is an autoimmune and neurodegenerative disease of the central nervous system (CNS) that is characterized pathologically by focal infiltration of leukocytes into the CNS white matter, resulting in oxidative stress, demyelination and axonal loss (Haider et al., 2011; Noseworthy et al., 2000; Smith, 2011; Trapp and Nave, 2008). To date the vast majority of disease modifying treatments (DMTs) are available for the relapsing-remitting forms of MS (RRMS), with an anti-CD20 B-cell depletion therapy, ocrelizumab, also approved for the treatment of primary progressive forms of the disease. The mechanism of action for these DMTs is, for the most part, to either induce a shift in the immune bias from pro-inflammatory to antiinflammatory, or limit the circulation or access to the CNS of pathogenic immune cells. This limits myelin destruction and relapses with the goal of reducing or stopping clinical decline. Although these DMTs are effective at reducing annual relapse rates, over time they do not offer a permanent solution to preventing disability and/or progression in a significant proportion of people with MS (Bomprezzi, 2015; Brunetti et al., 2013; Hartung et al., 2015; Hoy, 2015; McCormack, 2013; Ruck et al., 2015; Sanford, 2014). New therapies are needed that not only control inflammation but can also prevent disease progression, and provide protection and/or repair in the CNS.

Components of the renin-angiotensin system (RAS) have been identified as chemical mediators in the CNS and in neurological disease, with modes of action that are independent of blood pressure functions (Sumners et al., 2013). Classically, RAS has been defined by the actions of angiotensin I (Ang-I) and angiotensin II (Ang-II) with Ang-I formed from the cleavage of angiotensinogen by renin, and Ang-II formed from Ang-I by angiotensin converting enzyme 1 (ACE1). ACE2 was identified in 2000, and advances over the last 18 years have led to the discovery of a new arm of the RAS cascade. It is now considered that this peptide hormone system exists as a balance between the classical pro-vasoconstrictor, pro-oxidant, proinflammatory axis of ACE1, Ang-II and angiotensin type 1 receptor (AT1R), and the provasodilatory, anti-inflammatory, regulatory arm of ACE2, angiotensin 1-7 (A(1-7)) and its Gprotein coupled receptor Mas. A(1-7) is formed from Ang-II or angiotensin 1-9 via ACE2, and signaling via the ACE2/A1-7/Mas axis in the brain is associated with increased nitric oxide (NO) 
release, increased endothelial and neuronal nitric oxide synthase (NOS) activity, and decreased oxidative stress (Cerrato et al., 2012; Gironacci et al., 2013; Mecca et al., 2011; Mordwinkin et al., 2012; Xu et al., 2011). Of significance to MS are the findings that Ang-II, and its cognate receptor AT1R, are increased in MS brain lesions, and that increased signaling through AT1R is associated with sustained brain inflammation in mice with experimental autoimmune encephalomyelitis (EAE) (Lanz et al., 2010; Stegbauer et al., 2009). In addition, ACE1 levels are increased in the cerebral spinal fluid of MS patients whereas ACE2 levels are decreased, providing evidence for altered protective RAS homeostasis in MS (Kawajiri et al., 2009). As A(1-7) has been shown to counter-regulate the detrimental effects of Ang-II signaling in other non-MS disease models leading to more effective immune regulation and reduced CNS damage we hypothesized that A(1-7) may be a potential therapy for the treatment of MS. Here we report the effectiveness of A(1-7) as a therapeutic treatment in an immune driven mouse model of MS.

\section{Materials and Methods:}

\subsection{Induction of EAE:}

All mouse studies were performed in accordance and with approval from the University of Southern California Institutional Animal Care and Use Committee and within the guidelines set forth by the National Institutes of Health. 8-10 week old male C57BL/6 mice (Jackson Labs, Maine, $\mathrm{n} \geq 8$ mice per treatment dose and group) were inoculated subcutaneously (SQ) with $200 \mu \mathrm{g}$ of sterile filtered myelin oligodendrocyte glycoprotein corresponding to the peptide sequence 35-55 (MOG ${ }_{35-55}$ ) (CPC Scientific, California). One milliliter of 2mg/ml MOG $35-55$ was admixed with $1 \mathrm{ml}$ of $8 \mathrm{mg} / \mathrm{ml}$ heat-killed mycobacterium tuberculosis (M.Tub, BD, New Jersey) in Freund's adjuvant (Sigma-Aldrich, Missouri) until thoroughly emulsified, giving $1 \mathrm{mg} / \mathrm{ml} \mathrm{MOG}_{35-55}$ in Complete Freunds Adjuvant (CFA). Mice were anesthetized with ketamine $(85 \mathrm{mg} / \mathrm{kg})$ \& xylazine $(10 \mathrm{mg} / \mathrm{kg})$ and were then inoculated with MOG in two different sites (0.1ml each) on the flanks. Following immunization 250ng pertussis toxin (List Biological Laboratories, California) was given intraperitonealy (IP) and again 2 days later. Seven days following immunization mice received a second MOG immunization as described above in two alternate sites on the flank. The second round of inoculate was given in incomplete Freunds (no M.Tub) and mice did not receive the pertussis toxin. 


\subsection{Clinical Disease Assessment:}

Mice were evaluated and weighed daily, by a blinded to treatment assessor, for signs of clinical disease activity and were given a clinical disease score corresponding to the following criteria: 0 $=$ no symptoms as compared with non-immunized mice; $0.5=$ weight loss and/or subtle weakness in tail or gripping of hind limbs; $1=$ loss of muscle tone in tail and/or mild weakness in gripping of hind limbs; 1.5 = tail paralysis or very limp tail, hind limbs have very weak grip; 2 $=$ hind limb weakness, resulting in ataxia; $2.5=$ more severe ataxia and hind limb weakness where mouse may drag one limb occasionally but can still move joints; $3=$ mild paresis or paralysis of one (3.0) or both (3.5) hind limbs and possible incontinence, $4=$ complete paralysis of both hind limbs, 4.5 = paresis or paralysis of forelimbs, $5=$ loss of temperature control and inactivity. Any mouse with a score of 4.5 or higher, or a score of 4.0 for 3 consecutive days, was humanely euthanized.

\subsection{Generation of Mas Knockout Mice:}

Mas1 ${ }^{\text {tm1(KOMP)Vlcg }}$ knockout mice were generated by the trans-NIH Knock-Out Mouse Project (KOMP) and contained a neomycin cassette in place. F1 heterozygote Mas1 $1^{\text {tm1(KOMP)Vlcg }}$ C57BL/6N mice (MGI: 96918; Ensemble: ENSMUSG68037) were obtained from the KOMP Repository (www.komp.org) at UC Davis and bred to homozygosity in-house at the animal care facility of the University of Southern California. All breeding and experimental protocols were performed in accordance and with approval from the University of Southern California Institutional Animal Care and Use Committee and within the guidelines set forth by the National Institutes of Health. Homozygosity was confirmed by PCR using the primers Mas Wildtype Forward (5'-TGCTGAAGAGAAAGCCATGAATAC-3'), Mas Wildtype Reverse (5'AGATAGAGGCCCGTGTTGTAGCC-3') resulting in a 336bp product, Neo Forward (5'TCATTCTCAGTATTGTTTTGCC-3') and Neo Reverse (5'- GGTGCTTTGCCTACCTCATC-3' resulting in a 550bp product The phenotype and characteristics of Mas knockout deletion mice have been described previously (Alenina et al., 2008; Metzger et al., 1995; Walther et al., 1998).

\subsection{Drug Treatment:}

Therapeutic A(1-7) treatment was started at the first signs of clinical disease (CDS $\geq 0.5$ ), on an individual mouse basis, and was continued for up to 25 days following induction of EAE. 
Pharmaceutical grade A(1-7) was administered by either twice daily SQ injection (BiD) or by osmotic mini-pump (MP; Alzet ${ }^{\circledR}$ model 1004, Durect, California) SQ implantation for continuous delivery. For BiD treatments mice were injected with a twice daily bolus of $0.1 \mathrm{ml}$ A(1-7) (10-hrs apart) for total daily doses of $0.5,1,2$ or $4 \mathrm{mg} / \mathrm{kg}$. Vehicle control mice were also injected twice daily with saline. For MP continuous delivery, mice received a total daily dose 0 (saline), 0.5, 1, 2 or $4 \mathrm{mg} / \mathrm{kg} \mathrm{A(1-7)} \mathrm{infused} \mathrm{over} 24$ hours. Following anesthesia, pumps were implanted subcutaneously, at the first signs of clinical disease (CDS $\geq 0.5$ ), on an individual mouse basis.

\subsection{Histopathological Examination of CNS tissue:}

At study end (day 40) mice were euthanized with sodium pentobarbital overdose and transcardially perfused with cold saline and then $4 \%$ paraformaldehyde. Spinal cords were removed and further fixed in $4 \%$ paraformaldehyde or $70 \%$ ethanol for $18 \mathrm{hrs}$ at $4^{\circ} \mathrm{C}$. Subsequently cords were transferred to either a $20 \%$ sucrose solution for $24 \mathrm{hrs}$ and then snap frozen with methyl butane and stored at $-80^{\circ}$ for preparation of $20 \mu \mathrm{m}$ thick serial cryosections or were embedded in paraffin for preparation of $6 \mu \mathrm{m}$ thick serial tissue sections. The extent of demyelination, immune infiltration and axonal loss in the spinal cords of saline and $A(1-7)$ treated mice was semi-quantitatively assessed by histological staining for myelin content using solochrome cyanine, immune infiltrate using hematoxylin and eosin (H\&E) and axonal loss using Bielschowsky's silver stain. Solochrome cyanine staining for myelin was performed by deparaffinization of spinal cord sections on slides in xylene (for paraffin embedded sections only), rehydration in decreasing ethanol grades and was followed by incubation in distilled water overnight. The following day, tissue sections were again dipped through xylene, graded ethanol, and distilled water followed by incubation in solochrome cyanine solution (1g Eriochrome ${ }^{\circledR}$ Cyanine R (Sigma-Aldrich, Missouri), 2.5ml fuming sulfuric acid and $20 \mathrm{ml} 0.35 \mathrm{M} \mathrm{FeCl}_{3}$ in $500 \mathrm{ml}$ distilled water) for 20 minutes at room temperature. Subsequently, tissue sections were then washed in distilled water and destained with $0.35 \mathrm{M} \mathrm{FeCl}_{3}$ for 15 seconds with agitation. Sections were washed once more, counterstained with Van Gieson's solution (Electron Microscopy Sciences, Pennsylvania) for 3 minutes and were washed again with distilled water, then graded ethanols and finally with xylene. H\&E staining for cellular infiltration was performed again through deparaffinization of spinal cord sections on slides in xylene (for 
paraffin embedded sections only), rehydration in decreasing ethanol grades, and was followed by incubation in distilled water overnight. The following day, tissue sections were again dipped through xylene, graded ethanol, and distilled water followed by incubation in Hematoxylin solution (VWR, Pennsylvania) for 4 minutes at room temperature. Tissue sections were then washed in distilled water and counterstained with Eosin solution (VWR, Pennsylvania) for 1 second. The sections were washed again with distilled water, then graded ethanols and finally with xylene. Bielschowsky's silver staining for axons was performed again through deparaffinization of spinal cord sections on slides in xylene, rehydration in decreasing ethanol grades and then distilled water, followed by incubation in $2 \%$ silver nitrate solution for 48 hours at room temperature and protected from light. Subsequently tissue sections were washed in distilled water and then incubated with silver hydroxide solution (2\% silver nitrate containing ammonium hydroxide; ammonium hydroxide was added dropwise until solution turned clear) for 15 minutes at $37^{\circ} \mathrm{C}$. Following treatment, the sections were then washed in $0.1 \%$ ammonium hydroxide at room temperature before incubation in silver hydroxide solution containing $0.7 \%$ developer $(0.2 \mathrm{ml} 37 \%$ formaldehyde, $12 \mathrm{ml}$ distilled water, $12.5 \mu \mathrm{l} \mathrm{20 \%}$ nitric acid and $0.05 \mathrm{~g}$ citric acid) for 10 minutes at room temperature. The sections were then washed again in $0.1 \%$ ammonium hydroxide and distilled water and then fixed in 5\% sodium thiosulfate for 1 minute. The sections were washed again with distilled water, then graded ethanols and finally with xylene. For all stains, following the last dip in xylene, spinal cord sections were dried and coverslipped with Cytoseal (Electron Microscopy Sciences, Pennsylvania).

For semi-quantitative evaluation of myelin content and immune infiltration serial 20 $\mu m$ longitudinal sections encompassing the entire length and width of the spinal cord or serial $6 \mu \mathrm{m}$ cross sections of the cervical, thoracic and lumbar regions (approximately 16 spinal cord sections per mouse for each histological stain and at least 4 mice per treatment group) were evaluated globally, using light microscopy, by a blinded scorer and assigned a number (0-5) corresponding to the extent of demyelination and immune infiltrate using the following scoring criteria: $0=$ no demyelination, no perivascular cuffing and no cellular infiltration; 1 = minimal perivascular cuffing and no demyelination; 2 = perivascular cuffing, mild infiltration distal to blood vessels, loss of myelin integrity and no clearly defined lesion borders; 3 = perivascular cuffing, moderate to extensive cellular infiltration with clearly defined lesion borders; 4 = perivascular cuffing, 
extensive infiltration distal to blood vessels, multiple lesions with clearly defined borders and merging of smaller lesions and $5=$ extensive infiltrate at multiple sites with extensive lesions spanning multiple segments. For quantitative evaluation of axonal loss using Bielschowsky's silver stain, the areas (measured in $\mu^{2}$ ) of axon loss were manually outlined using CellSens software (Olympus, California) from serial $6 \mu \mathrm{m}$ cross sections corresponding to the lumbar region of the spinal cord. Approximately 4-6 spinal cord sections per slide from 3 mice per treatment group were assessed.

\subsection{Immunohistochemistry:}

Assessment of nitrotyrosine expression was performed using immunohistochemistry as described previously by (Papinska et al., 2016). Briefly, $6 \mu$ m paraffin-embedded, serial spinal cord tissue sections were treated with Antigen Retrieval Citra solution (Biogenex, California) and were blocked for endogenous avidin, biotin, and non-specific antibody binding for 2 hours with egg white buffer, milk buffer, and $10 \%$ goat serum, respectively. Sections were then incubated with rabbit anti-nitrotyrosine antibody (1:500, Millipore, Massachusetts) at room temperature for 1

hour. Labeling was followed by incubation with biotinylated goat anti-rabbit secondary antibody (1:1000, Thermo Fisher Scientific, Massachusetts) for 1 hour, and subsequent avidin-horse radish peroxidase reporter system for 30 minutes, and with DAB substrate for 10 minutes. Tissue sections were cover slipped and visualized by light microscopy at 60x magnification. Spinal cord sections from at least 3 mice per treatment group were probed and assessed.

\subsection{Immune Measures:}

\subsubsection{Proliferation Assay}

The immune response to the inoculating antigen following A(1-7) treatment was determined as previously described but with minor modifications (Lund et al., 2013). Briefly, spleens were harvested at the end of the experiment ( $\sim 0$ days after inoculation) and single-cell suspensions of splenocytes were generated by gently teasing apart the spleen with forceps and scissors then passing through a strainer using the plunger end of a syringe. The resulting cell suspension was washed in PBS and red blood cells lysed in BD Pharm Lyse (BD Biosciences, Franklin Lakes, NJ) followed by a final wash in PBS. The final pellet was resuspended in $5 \mathrm{ml}$ culture medium and $2 \times 10^{6}$ cells plated with or without varying concentrations of MOG peptide in quadruplicate 
in 96-well U-bottom tissue culture plates (200 $\mu$ l volume per well). Cells were cultured in RPMI1640 supplemented with 5\% FCS, 2 mM L-glutamine, $1 \mathrm{mM}$ sodium pyruvate and $0.1 \mathrm{mM}$ nonessential amino acids at $37^{\circ} \mathrm{C}, 5 \% \mathrm{CO} 2$. With the exception of FCS, all supplements were obtained from Thermo Fisher Scientific (Camarillo, CA); FCS was obtained from Omega Scientific (Tarzana, CA). After 24hrs of culture, 50 $\mu$ l of culture supernatants were collected from each well and stored at $-70^{\circ} \mathrm{C}$ until required for cytokine and chemokine assessments. After $48 \mathrm{hrs}$ of culture, each well was pulsed with $0.2 \mu \mathrm{Ci}{ }^{3} \mathrm{H}$-thymidine for $18 \mathrm{hrs}$. Plates were then harvested and the level of ${ }^{3} \mathrm{H}$ incorporation determined by scintillation counting (Wallac LKB, Liquid Scintillation Counter). Data were calculated as stimulation index, fold increase in cpm incorporation with stimuli over background cpm. Antigen-specific responses were calculated for splenocytes from $\mathrm{A}(1-7)$ treated animals $(2 \mathrm{mg} / \mathrm{kg} \mathrm{BiD}$ or $1 \mathrm{mg} / \mathrm{kg} \mathrm{MP}$ ) and compared to saline treated (BiD or MP) and also to healthy, non-immunized mice.

\subsubsection{Cytokine Bead Array:}

The concentrations of a large panel of solutes including IL-2, IL-4, IL-5, IL-6, IL-10, IL-13, IL17A, TNF, IFN $\gamma$, CCL2, CCL3, CCL5 and CXCL9 were simultaneously measured in culture supernatant samples using cytometric bead array (BD Biosciences, Franklin Lakes, NJ) as previously described but with minor modifications (Lund et al., 2004). Briefly, samples were thawed, serial dilutions (min. 1:2) made in the supplied dilution buffer, and samples incubated in the respective bead / fluorochrome pairs. Samples harvested from individual proliferation assay wells were run in triplicate and the average used to calculate the concentration of solutes in each sample. The concentration of each solute was calculated based on a standard curve of known concentrations and the intra-assay variability accounted for using internal control samples. The CBA sample data were collected using a BD Biosciences Accuri cytometer and analyzed using the commercially available FCAP Array Software (BD Biosciences, Franklin Lakes, NJ). The mean sample concentration is given as either femtogram or picograms per milliliter of culture supernatant.

\subsubsection{FACS analysis of leukocyte populations:}

The relative proportion of the major leukocyte populations within the spleen of $A(1-7)$ treated and control mice was assessed by multi-color FACS analyses using fluorochrome-conjugated 
monoclonal antibodies specific for key cell surface markers as previously described but with minor modifications (Lund et al., 2013). Single-cell suspensions of splenocytes ( $10^{6}$ per tube) were first incubated for 15mins with FcBlock (BioLegend, San Diego, CA) and $1 \mu \mathrm{g}$ normal mouse IgG to block non-specific staining, then for 30mins with various cocktails of monoclonal antibodies at pre-determined optimal dilutions. Debris identified by low FSC v SSC and doublets identified with higher FSC-A than FSC-H were first excluded, then the relative proportion of the following populations of leukocytes were measured using FSC vs. SSC criteria, CD45 staining intensity, and various combinations of lineage-specific antibodies: T lymphocytes $\left(\mathrm{CD}_{4} 5^{\mathrm{hi}}, \mathrm{CD}^{+}, \mathrm{CD}^{+}\right.$or $\left.\mathrm{CD}^{+}\right)$, monocytes and macrophages $\left(\mathrm{CD} 45^{\mathrm{hi}}, \mathrm{F} 4 / 80^{+}, \mathrm{CD} 11 \mathrm{~b}^{+}\right)$, dendritic cells $\left(\mathrm{CD} 45^{\text {hi }}, \mathrm{CD} 11 \mathrm{c}^{+}\right.$, MHC class $\left.\mathrm{II}^{\mathrm{hi}}\right)$ and polymorphonuclear cells (CD45 $5^{\text {int }}$,

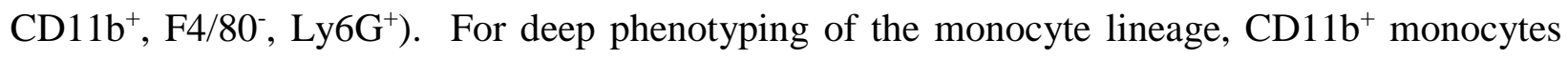
were examined for their relative co-expression of the markers CCR2 and Ly6C using a strategy based on that published by (Rose et al., 2012). Briefly, debris, doublets and dead cells were excluded as described above then non monocyte lineage cells $\left(\mathrm{CD} 4^{+}, \mathrm{CD} 8^{+}, \mathrm{CD} 19^{+}, \mathrm{NK} 1.1^{+}\right.$, $\mathrm{CD}_{11} \mathrm{c}^{\mathrm{hi}}$ and $\mathrm{Ly} 6 \mathrm{G}^{+}$) excluded using a "dump" channel. The relative proportion of the remaining cells which were classically activated $\left(\mathrm{Ly} \mathrm{C}^{\mathrm{hi}}, \mathrm{CCR} 2^{+}\right.$) and alternatively activated (Ly6C ${ }^{\mathrm{lo} / \mathrm{neg} \text {, }}$ CCR2 $^{-}$) were then determined using the qualitative gating strategy described by Rose and colleagues. All staining was analyzed using a FACS Canto II (BD Biosciences, Franklin Lakes, $\mathrm{NJ}$ ) with settings, PMT voltages and compensations defined in preliminary experiments and used throughout this study. Isotype control staining and appropriate gating strategies were used to calculate the relative proportion of splenocytes expressing the marker(s) of interest. All of the following antibodies used in this study were from BD Biosciences (Franklin Lakes, NJ) except where otherwise stated: anti-CD45 (OX-1), anti-CD3 (145-2C11), anti-CD4 (RM4-5), antiCD11b (M1/70), anti-CD11c (HL3), anti-F4/80 (6F12), anti-Ly-6G (1A8), anti-Ly-6C (AL-21), anti-CD8 (Biolegend, San Diego CA) and anti-CCR2 (Biolegend, San Diego CA).

\subsection{Data Analyses and Statistics:}

Mean \pm standard error of the mean (SEM) of the CDS were plotted against days post immunization (DPI) to show the progression of disease in each treatment group. The mean \pm SEM of the cumulative CDS was plotted against DPI and a linear regression was best fit to the data to calculate the average increase in clinical progression over time. The mean \pm SEM of 
lesion score, area of axon loss, immune measures and number of nitrotyrosine positive cells per area of interest was calculated for each treatment group. A correlation between either lesion scores, areas of axon loss, or number of nitrotyrosine positive cells versus respective clinical disease score was also tested. Pearson's correlation coefficient was used to test the strength of the correlation between clinical disease score and each parameter. Statistical differences over time and in the means between treatment groups were tested by one-way ANOVA and by paired or unpaired student $t$ test, where appropriate, for each parameter. A p-value of $<0.05$ was considered significantly significant where $*=p \leq 0.05, * *=p \leq 0.01$ and $* * *=p \leq 0.001$. Statistical analyses were performed using GraphPad Software, Inc. (California, USA).

\section{Results:}

\subsection{Treatment with A(1-7) reduced clinical disease severity and progression in MOG-EAE mice.} The efficacy of therapeutic A(1-7) treatment was assessed in EAE, a well-described and much used mouse model for MS that reflects many of the inflammatory and neurodegenerative aspects observed in MS (Kuchroo et al., 2002; Zamvil and Steinman, 1990). EAE induced in C57BL/6 mice by inoculation with $\mathrm{MOG}_{35-55}$ peptide shows a chronic disease course with mice developing an ascending hind-limb paresis, and once established treatment intervention can be very limited. In all studies mice were evaluated daily in a blinded fashion for clinical disease and following clinical evaluation mice were assigned a clinical disease score (CDS) using a well-established scale (Goverman et al., 1993; Louie et al., 2005; Weiner et al., 2004) (see also methods for scoring). In preliminary experiments (data not shown) we observed that therapeutic once daily SQ injection of $0.5 \mathrm{mg} / \mathrm{kg} \mathrm{A}(1-7)$ in the MOG-EAE model resulted in a modest reduction in disease course as compared with saline treatment. This modest effect, and the fact that the half life of A(1-7), following SQ injection, is 30mins, led us to assess the effect of twice daily treatment with $\mathrm{A}(1-7)$. Figure 1 shows dose-response findings when $\mathrm{A}(1-7)$ treatment, given by SQ BiD injection for a total dose of $0.5,1,2$ or $4 \mathrm{mg} / \mathrm{kg} / \mathrm{day}$, was initiated only when a given mouse had a CDS of $\geq 0.5$. For graphical reasons, in order to clearly show the differences between saline and individual A(1-7) doses, we have shown each dose versus saline in figures 1A-D, however, it should be noted that for this experiment all A(1-7) and saline treatments were run in parallel. In general, mice treated with A(1-7) showed improved clinical disease score over 
time. The most effective dose was $2 \mathrm{mg} / \mathrm{kg} / \mathrm{day} \mathrm{A}(1-7)$. Clinical disease score in the $2 \mathrm{mg} / \mathrm{kg} / \mathrm{day}$ A(1-7) treated mice (fig.1C) was reduced in all mice within 3-4 days of treatment onset and remained significantly lower than that of saline-treated mice through the end of the study. These mice had a peak mean CDS of $2.50 \pm 0.38$ on day 25 PDI (compared to saline-treated mice with a CDS of $3.57 \pm 0.18$ on day $22 \mathrm{PDI}$ ) and at study end had a mean CDS of $2.14 \pm 0.44$ (compared to saline-treated mice with a CDS of $3.04 \pm 0.28$ ). Mice treated with $4 \mathrm{mg} / \mathrm{kg} / \mathrm{day}$ (fig. 1D open diamonds) similarly had reduced clinical disease score though these mice showed a more varied disease course. Mice treated with $1 \mathrm{mg} / \mathrm{kg} /$ day A(1-7) (fig. 1B open squares) also had a significantly $(\mathrm{p}<0.001)$ reduced clinical disease score at various points over the course of the study though there was clearly reduced efficacy at this dose. In contrast, mice treated with $0.5 \mathrm{mg} / \mathrm{kg} /$ day A(1-7) (fig. 1A open circles) showed only a minor benefit of treatment with a significant ( $<<0.05$, fig. $1 \mathrm{~A}$ ) reduction in clinical disease score only observed at the early time points (days 14-24) as compared with saline treated mice. Cumulative clinical disease score (summation of daily CDS) was also plotted over time post-immunization (fig. 1G) and illustrates that each dose of $\mathrm{A}(1-7)$ was associated with a significant $(\mathrm{p}<0.001)$ reduction in the mean cumulative CDS as compared to mice which received saline only. Saline BiD mice increased an average of $2.67 \pm 0.09$ cumulative CDS points/day versus A(1-7) $2 \mathrm{mg} / \mathrm{kg} / \mathrm{day}$ BiD which increased an average of only $1.79 \pm 0.07$ cumulative CDS points/day.

Treatment with A(1-7) via twice daily injection showed efficacy in our hands, but this mode of administration may not be convenient for the patient population and could lead to feasibility issues in the development of this drug for use in humans. We therefore assessed continuous administration via the subcutaneous implantation of an osmotic minipump. This method would be akin to the use of slow-release medications. Using the same study design as in the first experiment, A(1-7) treatment was given by a subcutaneously implanted osmotic minipump (MP) in order to achieve a continuous total daily dose of $0.5,1,2$ or $4 \mathrm{mg} / \mathrm{kg}$. The data in figure 2 clearly show that in general mice treated with $A(1-7)$ showed improved clinical disease score over time. Again, for graphical reasons, in order to clearly show the differences between saline and individual $\mathrm{A}(1-7)$ doses, we have shown each dose versus saline in figures 2A-D, however it should be noted that for this experiment all $\mathrm{A}(1-7)$ and saline treatments were run in parallel, with blinded to treatment scoring. The most effective dose over time for continuous delivery 
was the $1 \mathrm{mg} / \mathrm{kg} /$ day A(1-7) group (fig. 2B open squares). Treatment with $1 \mathrm{mg} / \mathrm{kg} /$ day A(1-7) significantly $(\mathrm{p}<0.001)$ reduced clinical disease score over time compared to saline treated mice with a peak mean CDS of $2.42 \pm 0.42$ on day 29 PDI (compared to saline peak mean CDS of $3.48 \pm 0.16$ on day $20 \mathrm{PDI}$ ) and a mean CDS of $2.00 \pm 0.48$ at study end (compared to saline mean CDS of $3.22 \pm 0.22$ ). Interestingly the $2 \mathrm{mg} / \mathrm{kg} / \mathrm{day}$ (fig. $2 \mathrm{C}$ (open triangles) and $4 \mathrm{mg} / \mathrm{kg} /$ day (fig. 2C (open diamonds) continuous delivery groups, though demonstrating delayed disease progression from days 13-17 PDI, still developed a high level of disability that was similar in severity to the saline treated mice. However, it should be noted that in both of these groups of mice there was improvement in CDS over time following the peak CDS and that these improvements were significant at multiple time points during the experiment $(\mathrm{p}<0.05)$ (fig. $2 \mathrm{C}$, D \& E). At study end $2 \mathrm{mg} / \mathrm{kg} /$ day treated mice had a CDS of $2.30 \pm 0.41$ and $4 \mathrm{mg} / \mathrm{kg} / \mathrm{day}$ treated mice had a CDS of $2.70 \pm 0.22$ respectively as compared to saline (CDS of $3.22 \pm 0.22$ ). Treatment with $0.5 \mathrm{mg} / \mathrm{kg} / \mathrm{day} \mathrm{A}(1-7)$ (fig. $2 \mathrm{~A}$ open circles) significantly $(\mathrm{p}<0.05)$ delayed disease severity up until day 22 PDI compared with saline treated mice, after which A(1-7) treated mice showed a similar disease course to the saline treated mice. We again plotted the cumulative clinical disease scores (figure 2G) for each doses of $\mathrm{A}(1-7)$ and found that all were significantly $(\mathrm{p}<0.001)$ improved compared to saline MP treated mice: saline MP treated mice increased an average of $2.48 \pm 0.11$ cumulative CDS points/day versus A(1-7) $1 \mathrm{mg} / \mathrm{kg} / \mathrm{day}$ MP treated mice which increased an average of only $1.35 \pm 0.06$ cumulative CDS points/day. In addition, the cumulative disease score of the $1 \mathrm{mg} / \mathrm{kg}$ /day MP treated mice was significantly reduced ( $\mathrm{p}<0.01$ ) compared to the 0.5, 2 and $4 \mathrm{mg} / \mathrm{kg} /$ day A(1-7) MP doses. For both routes of delivery, $\mathrm{A}(1-7)$ treated mice had no significant differences in mean body weight compared to saline (BiD and MP) treated mice (figs. $1 \mathrm{~F} \& 2 \mathrm{~F}$ ), with the exception of the $1 \mathrm{mg} / \mathrm{kg} / \mathrm{day}$ MP A(1-7) treated mice ( $<<0.001$ vs. saline MP). This group maintained body weight throughout the course of disease.

To confirm that the beneficial effects of A(1-7) on clinical disease course in the MOG-EAE model were due to Mas receptor activation, we induced EAE in Mas knockout mice and treated them with the most optimal dose of $\mathrm{A}(1-7)$ (2mg/kg/day BiD SQ). Again, mice were evaluated daily in a blinded fashion for clinical disease and assigned a clinical disease score (CDS), and treatment was not commenced until after clinical disease onset (CDS $\geq 0.5)$. Figure 3 shows that 
there was no benefit of A(1-7) treatment in Mas knockout (KO) mice. The CDS in 2mg/kg/day $\mathrm{BiD}$ A(1-7) treated Mas KO mice was similar to that of saline-treated Mas KO and wild type mice. $2 \mathrm{mg} / \mathrm{kg} /$ day A(1-7)-treated Mas KO mice had a peak mean CDS of 2.30 \pm 0.57 on day 24 PDI compared to saline-treated Mas KO mice with a CDS of $2.10 \pm 0.45$ on day 21 PDI. At study end, A(1-7)-treated Mas KO mice had a CDS of $1.95 \pm 0.37$ compared to saline-treated Mas KO mice with a CDS of $1.75 \pm 0.16$ (fig. 3). There were no statistically significant differences between the test groups of mice confirming that the beneficial effect of $A(1-7)$ treatment is via modulation of the receptor for A(1-7), Mas.

\subsection{Treatment with A(1-7) reduced demyelination, mononuclear cell infiltration, axonal loss and} oxidative stress in the spinal cords of MOG-EAE mice.

To determine whether the improvement in clinical disease score correlated with improvements in disease histopathology, the spinal cords from saline and A(1-7) treated mice were evaluated for measures of myelin content, mononuclear cell infiltration, axonal loss and oxidative stress. In order to semi-quantitatively assess lesion burden, serial $20 \mu \mathrm{m}$ longitudinal or $6 \mu \mathrm{m}$ coronal tissue sections spanning the length of the spinal cord were stained with solochrome cyanine (to evaluate myelin content) or hematoxylin and eosin ( $\mathrm{H} \& \mathrm{E}$, to evaluate immune infiltrate). Approximately 16 spinal cord sections per mouse for each histological stain and 4 mice per treatment group were evaluated globally by a blinded scorer and assigned a number corresponding to the extent of demyelination and immune infiltrate using the scoring criteria detailed in the methods section. There was a very strong positive correlation $\left(\mathrm{r}^{2}=0.8061\right)$ between lesion score and corresponding CDS (fig. 4A) thus demonstrating the validity of this assessment. In $\mathrm{BiD} \mathrm{A}(1-7)$ treated MOG-EAE mice a dose-dependent reduction in lesion score was observed (fig. 4B). Both $2 \mathrm{mg} / \mathrm{kg} /$ day A(1-7) treated mice (mean lesion score $2.18 \pm 0.22$ ) and $4 \mathrm{mg} / \mathrm{kg} /$ day A(1-7) treated mice (mean lesion score $1.86 \pm 0.35)$ had significantly $(\mathrm{p}<0.05)$ less demyelination and immune infiltration in the spinal cord compared to saline treated mice (mean lesion score of $3.13 \pm 0.30$ ) at study end. Similarly, the most effective dose in the MP treated group, $1 \mathrm{mg} / \mathrm{kg} /$ day $\mathrm{A}(1-7)$ (mean lesion score $0.77 \pm 0.20$ ), also had significantly $(\mathrm{p}<0.001)$ less demyelination and immune infiltration in the spinal cord compared to saline MP treated mice (mean lesion score $3.14 \pm 0.3$ ) (fig. 4C). Interestingly, the $2 \mathrm{mg} / \mathrm{kg} / \mathrm{day}$ and 4mg/kg/day A(1-7) MP treated mice also demonstrated reduced demyelination and immune 
infiltration compared to the saline treated MP mice with mean lesion scores of $1.70 \pm 0.23$ $(\mathrm{p}<0.001)$ and $2.50 \pm 0.16(\mathrm{p}<0.01)$ respectively (fig. 4C).

As axonal degeneration is a major component of MS as well as in MOG-EAE (Kearney et al., 2015; Kumar et al., 2013; Ozturk et al., 2010) the effect of A(1-7) treatment on axonal loss was evaluated in MOG-EAE spinal cords collected at study end. The lumbar region of the spinal cord is severely affected in MOG-EAE exhibiting axonal degeneration in symptomatic MOGEAE. We therefore assessed axonal integrity/loss in the gracile fasciculus and post synaptic dorsal column pathway of the lumbar spinal cord using Bielschowsky's silver stain (see figure 4D for representative histological sections). We assessed axonal staining in the spinal cords of mice treated with the optimal doses of A(1-7), namely $2 \mathrm{mg} / \mathrm{kg} / \mathrm{day} \mathrm{BiD}$ and $1 \mathrm{mg} / \mathrm{kg} / \mathrm{day} \mathrm{MP}$. In spinal cords from $2 \mathrm{mg} / \mathrm{kg} / \mathrm{day}$ BiD A(1-7) treated mice we saw significant preservation $(\mathrm{p}<0.05)$ of axons compared with saline treated mice (fig. 4Ei). A(1-7) treated mice only had $1295 \pm 944 \mu \mathrm{m}^{2}$ of axonal loss of, whereas saline BiD treated mice had $9841 \pm 4342 \mu \mathrm{m}^{2}$ of axonal loss. Similarly, mice treated with A(1-7) by continuous SQ infusion lost significantly $(\mathrm{p}<0.01)$ less axons than mice treated with saline alone; $4599 \pm 1985 \mu \mathrm{m}^{2}$ of axonal loss in $1 \mathrm{mg} / \mathrm{kg} /$ day $\mathrm{A}(1-7)$ as compared to $11833 \pm 1479 \mu \mathrm{m}^{2}$ of axonal loss of in the saline MP treated group (fig. 4Fi). These findings clearly demonstrate that $\mathrm{A}(1-7)$ treatment is associated with a significant attenuation of axon loss in the lumbar spinal cord region. It is important to note that these measures do not allude to the functionality of the axons, but merely to their presence in the tissue.

Oxidative stress has also been implicated as a key mediator of MS pathology (Haider et al., 2011; Liu et al., 2015; Smith, 2011) and stimulation of Mas by A(1-7) has been shown to reduce infarct size and ameliorate neurological deficits in animal models of stoke by activation of neurotrophic, anti-inflammatory and oxidative stress pathways (Cerrato et al., 2012; Gironacci et al., 2013; Jiang et al., 2013; Jiang et al., 2014; Mecca et al., 2011; Mordwinkin et al., 2012; Xu et al., 2011; Zheng et al., 2014a; Zheng et al., 2014b). We therefore assessed the effect of A(1-7) treatment on the expression of 3-nitrotyrosine, a marker of oxidative stress, in the spinal cords of MOG-EAE mice treated with the optimal doses of $\mathrm{A}(1-7)$, namely $2 \mathrm{mg} / \mathrm{kg} / \mathrm{day} \mathrm{BiD}$ and $1 \mathrm{mg} / \mathrm{kg} /$ day MP. Figures 4Eii and 4Fii show the mean number of 3-nitrotyrosine positive cells 
in the gracile fasciculus and post synaptic dorsal column of the lumbar spinal cord following treatment with $\mathrm{A}(1-7)$ as compared to saline. The spinal cords of mice treated with $2 \mathrm{mg} / \mathrm{kg} / \mathrm{day}$ BiD A(1-7) had a significant reduction $(\mathrm{p}<0.05)$ in the mean number of 3-nitrotyrosine positive cells compared to saline $\mathrm{BiD}$ treated mice; $46.95 \pm 4.97$ positive cells with $\mathrm{A}(1-7)$ versus $65.44 \pm 5.92$ positive cells with saline (fig. 4Eii). In contrast, treatment with $1 \mathrm{mg} / \mathrm{kg} / \mathrm{day}$ MP $\mathrm{A}(1-7)$ did not result in a reduction in the number of 3-nitrotyrosine positive cells as compared to saline MP treated mice (fig. 4Fii).

3.3 Treatment with A(1-7) modified peripheral immune response to the inoculating antigen in EAE mice.

MOG-EAE is an inflammatory driven demyelinating model of MS and some of the actions of the A(1-7)/Mas axis, in other non-MS disease models, have been attributed to be in part due to modulation of the immune response (Khajah et al., 2017; Oliveira-Lima et al., 2015). We therefore assessed the capacity of $\mathrm{A}(1-7)$ to alter adaptive and innate immune responses in animals with EAE. We first assessed the proliferative response of splenocytes, harvested at study end (day 40), to the inoculating antigen $\mathrm{MOG}_{35-55}$ in saline and $\mathrm{A}(1-7)$ treated EAE mice. Figure 5 shows that there was a dramatic reduction in proliferative response to $\mathrm{MOG}_{35-55}$ $(20 \mu \mathrm{g} / \mathrm{ml})$ associated with both treatment paradigms. Whereas splenocytes from healthy, nonimmunized mice showed no response to $\mathrm{MOG}_{35-55}$ (white bars), splenocytes isolated from BiD saline treated mice (fig.5A, black bar) and minipump saline treated mice (fig.5B, black bar) mounted the expected robust proliferative response. The proliferative response of splenocytes following treatment with $2 \mathrm{mg} / \mathrm{kg} /$ day $\mathrm{BiD} \mathrm{A(1-7)} \mathrm{(grey} \mathrm{bar,} \mathrm{mean} \mathrm{stimulation} \mathrm{index} \mathrm{of}$ $1.44 \pm 0.23)$ was significantly $(\mathrm{p}<0.05)$ decreased compared to saline BiD treated mice (black bars, mean stimulation index of $2.49 \pm 0.46$ ). This reduction was not a complete suppression of the proliferative response as there was still a significant $(\mathrm{p}<0.05)$ response to the inoculating antigen in splenocytes isolated from $2 \mathrm{mg} / \mathrm{kg} / \mathrm{day} \operatorname{BiD~A(1-7)~treated~mice~as~compared~to~}$ control non-immunized mice (white bars, mean stimulation index of $0.69 \pm 0.11$ ). Interestingly, though there was a marked reduction in the proliferative responses in $1 \mathrm{mg} / \mathrm{kg} / \mathrm{day}$ MP A(1-7) treated mice versus saline MP at study end, day 40 PDI (fig. 5B), this did not reach significance. Similar trends were seen with all concentrations of MOG tested $(5 \mu \mathrm{g} / \mathrm{ml}$ and $50 \mu \mathrm{g} / \mathrm{ml}$, data not shown). 
We next examined the repertoire of cytokines and chemokines secreted by splenocytes in these cultures. There were no significant differences between the $2 \mathrm{mg} / \mathrm{kg} / \mathrm{day} \mathrm{BiD} \mathrm{A}(1-7)$ treated group versus saline $\mathrm{BiD}$ in the concentrations of the pro-inflammatory cytokines IL-2, IL-17A, and TNF (fig. 6Ai-iii). Interestingly, treatment in the $2 \mathrm{mg} / \mathrm{kg} / \mathrm{day} \mathrm{BiD} \mathrm{A}(1-7)$ treated group resulted in an increase in the concentration of IFN $\gamma(44026 \pm 15037 \mathrm{fg} / \mathrm{ml})$ compared to the saline $\mathrm{BiD}$ treated group $(6537 \pm 577 \mathrm{fg} / \mathrm{ml})$, however this increased secretion did not reach significance $(p=0.086)$ due to the large variability in this measure. There were however, significant increases with A(1-7) treatment in the secretion of IL-6 (27982 $\pm 7952 \mathrm{fg} / \mathrm{ml}$ vs. saline $3422 \pm 1500 \mathrm{fg} / \mathrm{ml}$; $\mathrm{p}<0.05)$ and the anti-inflammatory Th2 cytokines IL-4 $(699 \pm 130 \mathrm{pg} / \mathrm{ml}$ vs. saline 30 $\pm 13 \mathrm{pg} / \mathrm{ml}$; $\mathrm{p}<0.01)$ and IL-5 (690 $\pm 87 \mathrm{pg} / \mathrm{ml}$ vs. $30 \pm 6 \mathrm{pg} / \mathrm{ml}$; $\mathrm{p}<0.01)$. A similar trend was also observed in the $1 \mathrm{mg} / \mathrm{kg} /$ day MP A(1-7) treated group versus saline MP in that there were no significant differences in the concentrations of pro-inflammatory cytokines, but a significant $(\mathrm{p}<0.05)$ increase in the concentration of the Th2 cytokine IL-4 compared to saline treatment (fig. 6B, $526 \pm 140 \mathrm{pg} / \mathrm{ml}$ vs. $30 \pm 13 \mathrm{pg} / \mathrm{ml}$ ) Treatment with $2 \mathrm{mg} / \mathrm{kg} /$ day $\mathrm{BiD} \mathrm{A}(1-7)$ also demonstrated increases in the concentrations of MCP-1, MIG, RANTES and MIP1 $\alpha$ (fig. 6Aiii) versus saline following stimulation with inoculating antigen. This response was not observed in the 1 $\mathrm{mg} / \mathrm{kg} /$ day MP A(1-7) treated group.

In our next series of experiments we assessed the leukocyte composition within splenocytes at study end (day 40) to determine if $\mathrm{A}(1-7)$ treatment was associated with preferential expansion/recruitment of any given population(s). These analyses demonstrated that in mice treated with $2 \mathrm{mg} / \mathrm{kg} / \mathrm{day} \mathrm{BiD} \mathrm{A}(1-7)$ (fig.7A) there were significant $(\mathrm{p}<0.05)$ increases in the proportion of $\mathrm{F} 4 / 80^{+}, \mathrm{CD} 11 \mathrm{~b}^{+}$monocytes $\left(31.5 \pm 2.6 \%\right.$ vs. $25.5 \pm 1.9 \%$ saline) and $\mathrm{Ly}^{+} \mathrm{G}^{+}$ polymorphonuclear cells (18.5 $\pm 0.6 \%$ vs. $13.4 \pm 1.0 \%$ saline) in the spleen as compared to saline. There were also increases in the monocyte and polymorphonuclear cell populations in mice treated with $1 \mathrm{mg} / \mathrm{kg} /$ day MP A(1-7) though this did not reach significance. In contrast there were no changes in T lymphocyte populations $\left(\mathrm{CD}^{+}\right.$and $\left.\mathrm{CD} 8^{+}\right)$as a whole, or dendritic cells $\left(\mathrm{CD} 11 \mathrm{c}^{+}\right)$in mice treated with $2 \mathrm{mg} / \mathrm{kg} /$ day $\mathrm{BiD} \mathrm{A}(1-7)$. However, mice treated with 1 $\mathrm{mg} / \mathrm{kg} /$ day MP A(1-7) versus saline showed a significant $(\mathrm{p}<0.05)$ decrease in the size of both the $\mathrm{CD}^{+}$and $\mathrm{CD}^{+} \mathrm{T}$ cell populations within the spleen. CD4 $\mathrm{T}$ cells were reduced from 
$16.5 \pm 0.9 \%$ with saline treatment to $11.8 \pm 2.9 \%$ with MP A(1-7) treatment and CD8 T cells were reduced from $10.1 \pm 0.9 \%$ to $6.5 \pm 0.9 \%$.

These data suggested that treatment with A(1-7) was associated with changes in the composition of peripheral immune cells. Indeed, in both optimal doses there was an expansion of myeloid lineage cells and at least a trend to decreased representation of adaptive components. Given that we saw changes in the adaptive immune responses to the inoculating antigen (both proliferation and cytokine expression) we postulated that this could be due to A(1-7) associated changes in the monocyte/macrophage compartment. We therefore assessed the relative pro-/anti-inflammatory bias of the circulating monocytes/macrophages. Using multi-color FACS analyses we analyzed $\mathrm{CD}_{11} \mathrm{~b}^{+}$monocytes within the spleen to assess their relative co-expression of markers suggestive of a more pro-inflammatory function (classically activated (CAM): CCR2 ${ }^{+}$, Ly6C ${ }^{\text {hi }}$ ) versus those markers suggestive of a more anti-inflammatory function (alternatively activated (AAM): CCR2 $^{\text {neg }}$, Ly6C ${ }^{\text {lo/neg }}$ ) using a strategy based on that published by (Rose et al., 2012). Figure 8A shows that in mice treated with $2 \mathrm{mg} / \mathrm{kg}$ /day $\mathrm{A}(1-7)$ there was a significant $(\mathrm{p}<0.05)$ increase in the proportion of AAM within the spleen compared to saline treated mice. The percentage of AAM increased from $3.7 \pm 0.31 \%$ in saline treated mice to $6.8 \pm 1.46 \%$ in the $\mathrm{A}(1-7)$ treated mice. This increased proportion of AAM was not observed in the mice treated with $1 \mathrm{mg} / \mathrm{kg} / \mathrm{day} \mathrm{A}(1-7)$ delivered via minipump (fig.8Aii). We also examined culture supernatants of purified CD11 $\mathrm{b}^{+}$ monocytes for the secretion of cytokines purported to delineate functional activity, including IL6, IL-12, IL-10 and TGF $\beta$. Though there was increased IL-10 secretion by CD11b ${ }^{+}$monocytes from $1 \mathrm{mg} / \mathrm{kg} /$ day MP A(1-7) treated animals, this did not reach significance due to the high variability in these samples (fig. 8B).

\section{Discussion:}

Here we present novel data demonstrating the benefit of therapeutic A(1-7) treatment in an autoimmune driven model of MS, MOG-EAE. We also provide compelling evidence to support the role of RAS in the pathophysiology of inflammatory demyelination and, importantly, highlight the A(1-7)/Mas axis as a therapeutic target for the treatment of MS. Our data clearly showed, using multiple delivery routes, that therapeutic treatment with A(1-7) (started only when 
a mouse showed clinical symptoms: $\mathrm{CDS} \geq 0.5$ ) not only altered the disease course but also significantly reduced disease severity. The optimal doses in our hands for A(1-7) treatment were $2 \mathrm{mg} / \mathrm{kg} /$ day in the $\mathrm{BiD}$ group and $1 \mathrm{mg} / \mathrm{kg} /$ day in the MP continuous delivery group. Mice treated with these optimal doses had a clinical score of $~ 2.0$ at study end (day 40 post-disease immunization) and showed only hind limb weakness with mild ataxia whereas saline treated mice, with a clinical score $\sim 3.0$, showed severe hind limb paresis and/or paralysis of at least one hind limb. This clinical benefit of A(1-7) treatment occurs via modulation of the Mas receptor since no clinical benefit on disease course was observed in A(1-7)-treated EAE mice that were lacking the Mas receptor.

Histopathological analyses at study end of the spinal cords of mice treated with the optimal dose of $A(1-7)$ demonstrated that the improvements in clinical EAE disease course correlated with reductions in demyelination, axonal loss and immune infiltration. In a recent study by Hammer et al. (2016) prophylactic once daily SQ administration of AVE0991, a selective Mas receptor agonist, 3 days prior to immunization with MOG, significantly reduced EAE disease incidence with a slightly ameliorated clinical EAE course (Hammer et al., 2016). Interestingly, whilst not observed in the present study, the Hammer et al. (2016) publication also demonstrated that EAE disease course was significantly exacerbated in Mas receptor knockout mice. Previous studies by others have also revealed the importance of pharmacological intervention and the RAS pathway in MS as blockade of Ang-II signaling by ACE1 inhibitors or AT1R antagonists reduced the clinical severity of EAE (Platten et al., 2009; Stegbauer et al., 2009). However in these studies, though the clinical severity of EAE was reduced, targeting the Ang-II/AT1R/ACE1 pathway by way of treatment with losartan (AT1R antagonist) was accompanied with significantly lowered blood pressure (Stegbauer et al., 2009). RAS regulation of blood pressure is controlled by two opposing arms, the Ang-II/AT1R/ACE arm and the A(1-7)/Mas/ACE2 arm in which Ang-II causes increased blood pressure via stimulation of AT1R, while A(1-7), via Mas, counter regulates the actions of Ang-II to cause NO and prostaglandin release, vasodilation and decreased blood pressure. It should be noted that administration of high concentrations (nanomicromolar) of $\mathrm{A}(1-7)$ in normal non-hypertensive rodents does not cause a decrease in blood pressure and that Mas physiologically antagonizes AT1R (Kostenis et al., 2005; Santos et al., 2000). 
In experiments examining potential mechanisms of action responsible for the improvements in clinical and pathological disease course we show that treatment with $\mathrm{A}(1-7)$ was associated with a reduction in oxidative stress and increases in the anti-inflammatory bias of the immune response. Given that oxidative stress has been implicated as a key mediator of MS pathology (Haider et al., 2011; Liu et al., 2015; Smith, 2011) and as A(1-7) has been shown in other nonMS neurological studies to reduce oxidative stress in the brain (Jiang et al., 2013; Zheng et al., 2014a; Zheng et al., 2014b), we examined whether therapeutic treatment with A(1-7) in MOGEAE also resulted in reduced oxidative stress. Our data demonstrated, in spinal cord tissue taken at study end (day 40) that there was a significant reduction in the expression of the oxidative stress marker 3-nitrotyrosine in $2 \mathrm{mg} / \mathrm{kg} /$ day $\mathrm{BiD} \mathrm{A}(1-7)$ treated EAE mice compared to saline BiD treated EAE mice. It should be noted that these measures were assessed at study end, and do not reflect events that may be occurring at the earlier stages of the disease. This is the most likely reason why no changes were observed in the $1 \mathrm{mg} / \mathrm{kg} /$ day MP treated EAE group. It is considered that the functional roles of the two separate RAS pathways are to balance the production of reactive oxygen species (ROS) and NO, as well as inflammation in the brain and periphery. Increases in the activation of the AT1 receptor could contribute to disease pathology in the CNS by way of driving increases in microglial NADPH oxidase activity and ROS production (Labandeira-Garcia et al., 2017), whereas several studies have suggested a neuroprotective role for A(1-7)/Mas by decreasing ROS production, increasing NOS and altering immune bias and contribution in the brain. Jiang et al. (2013) demonstrated reductions in oxidative stress and attenuated neuronal apoptosis in the brains of hypertensive rats treated with A(1-7) (Jiang et al., 2013). Reductions in brain damage with improved neurological outcome have also been observed in ischemic stroke models in which A(1-7) was delivered systemically or intracerebrally either pre- or post injury (Bennion et al., 2018; Jiang et al., 2014; Mecca et al., 2011). Moreover, using a congestive heart failure model in which mice demonstrated significant cognitive impairment, Hay et al. (2017) demonstrated that although systemic treatment with A(17) failed to impact cardiac function, cognitive impairment (as measured by spatial memory and object recognition dysfunction) was attenuated compared to vehicle treated mice (Hay et al., 2017). In other non-MS neurological studies in which the effect of $A(1-7)$ treatment has been explored, a role for $\mathrm{A}(1-7)$ in the prevention demyelination and axonal damage has been also demonstrated: A(1-7) delivered directly into the hypothalamus prevented demyelination and 
axonal damage induced by Shiga toxin type 2 (Gironacci et al., 2013). In models of Parkinson's Disease the importance of RAS to disease pathogenesis and a neuroprotective role for A(1-7) has also been shown by 1) expression of Mas on dopaminergic neurons and glial cells in the substantia nigra and 2) intra-striatal post-administration of $\mathrm{A}(1-7)$ led to increased tyrosine hydroxylase expression and striatal dopamine content as well as an upsurge in the expression of Mas activated downstream targets PI3K, Akt, CREB and BDNF (Costa-Besada et al., 2018; Labandeira-Garcia et al., 2014; Rabie et al., 2018). Interestingly, in the present study, treatment with 2 and $4 \mathrm{mg} / \mathrm{kg} /$ day A(1-7) via continuous MP delivery demonstrated significantly improved clinical disease over time. This finding, in the inflammatory demyelinating EAE model, may suggest potential remyelination and warrants further investigation to determine if $A(1-7)$ can promote remyelination, or whether these observations are due to reductions and clearances of the massive immune cell infiltration in the CNS. Whilst a regenerative role for A(1-7) has not been demonstrated in the CNS, the effects of $\mathrm{A}(1-7)$ on peripheral wound healing and stem cell mobilization from the bone marrow may indicate a new therapeutic avenue for $A(1-7)$ and the treatment of MS (Abdallah et al., 2016; Papinska et al., 2015).

In the present study, analyses of immune system measures suggest that treatment with A(1-7) in the MOG-EAE mouse model affects the immune response differently based on the method of delivery (BiD vs. MP). BiD delivery appeared to more measurably affect the innate myeloid leukocyte populations whereas MP delivery more measurably affected the lymphocyte populations. Both delivery modes however resulted in a shift in the overall immune response to one with an anti-inflammatory bias. This was demonstrated by increases in antigen-specific secretion of the anti-inflammatory cytokines IL-4 and IL-5, as well increases in the levels of MCP-1, MIG, RANTES and MIP-1 $\alpha$ in the $2 \mathrm{mg} / \mathrm{kg} /$ day BiD treatment group. In contrast, there was no significant reduction in the expression of IL-2, TNF or IL-17A in any of the different treatment paradigms. Though somewhat surprising, this may be reflective of the stage of assessment of these solutes which were analyzed at the end of the experiment. Perhaps in the earlier stages of intervention when the treated versus untreated groups diverge clinically there may have been a more pronounced and detectable change in the expression of pro-inflammatory cytokines. Further analysis of changes in the myeloid lineage revealed that treatment with 2 $\mathrm{mg} / \mathrm{kg} /$ day $\mathrm{BiD} \mathrm{A}(1-7)$ was associated with a significant increase in the percentage of monocytes 
with a phenotype consistent with a more anti-inflammatory function namely: CCR2 ${ }^{\text {neg }}$, Ly6C $^{\text {lo/neg }}$. While surprisingly not observed in MP treated mice this again may be simply due to the timing of phenotype analyses. Interestingly, a functional change in bone-marrow derived macrophage (BMDM) responses was previously observed in Mas knockout mice. In these mice BMDM, which could not receive A(1-7) input, had increased transmigration and were biased toward a pro- rather than anti-inflammatory phenotype compared to BMDM from wild type mice (Hammer et al., 2016). This clearly suggests that A(1-7) regulates the activity of these cells via Mas to be functionally more regulatory and support our ex-vivo observations of increased potential for functional regulation in mice following A(1-7) treatment. In other studies, research has demonstrated that prophylactic use of the ACE inhibitor, lisinopril, or the AT1R antagonist, candesartan, led to a suppression of autoreactive Th1 and Th17 cells and promoted antigen specific $\mathrm{CD}^{+} \mathrm{FoxP}^{+}$regulatory $\mathrm{T}$ cells in EAE induced with proteolipid protein (PLP) (Platten et al., 2009). In the MOG-EAE model, prophylactic treatment with enalapril, an ACE1 inhibitor, and losartan, an AT1R antagonist, led to amelioration of clinical EAE disease course with significantly reduced numbers of $\mathrm{CD} 11 \mathrm{~b}^{+}$or $\mathrm{CD}_{11 \mathrm{c}^{+}} \mathrm{APC}$ in the spleen and spinal cord compared to untreated EAE mice (Stegbauer et al., 2009). Whilst the altered immune responses following treatment with $A(1-7)$ in the current study correlate with the clinical improvement seen in the cohorts of mice and suggest that an action of $\mathrm{A}(1-7)$ is to cause, either directly or indirectly, modulation of the immune response to the inoculating antigen, it is not clear if these immune changes are drivers of the clinical benefit observed. Mas is expressed extensively within the CNS (Freund et al., 2013; Hammer et al., 2016; Renno et al., 2012; Sumners et al., 2013) and therefore direct neuroprotective/anti-oxidant benefits of A(1-7) may be responsible for some of the clinical and histological improvements observed in the MOG-EAE model. This suggestion, along with whether the actions of $\mathrm{A}(1-7)$ in the present study promote remyelination require further investigation.

\section{Conclusions}

In this study, the in vivo efficacy of A(1-7), using two different modes of administration, was investigated in the $\mathrm{MOG}_{35-55}$ peptide-induced EAE model of MS. Therapeutic treatment with A(1-7) resulted in a dose-dependent reduction in clinical disease onset and severity, and was 
dependent on Mas receptor activation. Reductions in clinical disease score correlated with reductions in immune infiltration, demyelination and axonal loss in the spinal cords of EAE A(17) treated mice as compared to saline treated EAE mice. Further, examination of tissues at study end (day 40) demonstrated decreases in the levels of oxidative stress and modulation of the immune phenotype that was dependent on dose and route of administration. The results of these studies demonstrate A(1-7) in vivo efficacy and suggest use of this peptide as a potential new therapy for the treatment of MS.

\section{Funding}

This work was supported by the United States Department of Defense (B. L., grant number MS130053, 2017); the Southern California Clinical and Translational Science Institute (E. K., SC CTSI grant 8UL1TR000130, 2014) and the National Multiple Sclerosis Society (E. K., grant number RG-1607-25032, 2020).

\section{Declaration of Interest}

E. $\mathrm{K}$ has received investigator initiated research funding from Teva Pharmaceutical Industries and Novartis Pharmaceuticals Corporation. B. L. received investigator initiated research funding from Teva Pharmaceutical Industries, Novartis Pharmaceuticals Corporation and SanofiGenzyme. He has also received honoraria from Teva Pharmaceutical Industries. K. R has no industry related conflicts regarding research in multiple sclerosis. E. K., B. L. and K. R. are inventors of U.S. Patent No. 9,623,084. S. R., A. L., S. L., E. A. and N. K. have no declarations of interest to declare.

\section{Author contributions}

B. L., K. R. and E. K. planned the overall study. R. S., B. L. and E. K. performed the experiments, analyzed the data, wrote the manuscript (along with scientific advice from K.R.) and contributed equally to the work. A. L, S. L, E. A and N. K. provided technical expertise 
with the drug treatments, EAE clinical disease scoring, histology and immune measures, and all reviewed the manuscript.

\section{References}

Abdallah, W.F., Louie, S.G., Zhang, Y., Rodgers, K.E., Sivok, E., G, S.d., Humayun, M.S., 2016. NorLeu3A(1-7) Accelerates Clear Corneal Full Thickness Wound Healing. Invest Ophthalmol Vis Sci 57, 2187-2194.

Alenina, N., Xu, P., Rentzsch, B., Patkin, E.L., Bader, M., 2008. Genetically altered animal models for Mas and angiotensin-(1-7). Exp Physiol 93, 528-537.

Bennion, D.M., Jones, C.H., Donnangelo, L.L., Graham, J.T., Isenberg, J.D., Dang, A.N., Rodriguez, V., Sinisterra, R.D.M., Sousa, F.B., Santos, R.A.S., Sumners, C., 2018. Neuroprotection by post-stroke administration of an oral formulation of angiotensin-(1-7) in ischaemic stroke. Exp Physiol 103, 916-923.

Bomprezzi, R., 2015. Dimethyl fumarate in the treatment of relapsing-remitting multiple sclerosis: an overview. Ther Adv Neurol Disord 8, 20-30.

Brunetti, L., Wagner, M.L., Maroney, M., Ryan, M., 2013. Teriflunomide for the treatment of relapsing multiple sclerosis: a review of clinical data. Ann Pharmacother 47, 1153-1160.

Cerrato, B.D., Frasch, A.P., Nakagawa, P., Longo-Carbajosa, N., Pena, C., Hocht, C., Gironacci, M.M., 2012. Angiotensin-(1-7) upregulates central nitric oxide synthase in spontaneously hypertensive rats. Brain Res 1453, 1-7.

Costa-Besada, M.A., Valenzuela, R., Garrido-Gil, P., Villar-Cheda, B., Parga, J.A., Lanciego, J.L., Labandeira-Garcia, J.L., 2018. Paracrine and Intracrine Angiotensin 1-7/Mas Receptor Axis in the Substantia Nigra of Rodents, Monkeys, and Humans. Mol Neurobiol 55, 5847-5867.

Freund, M., Walther, T., von Bohlen Und Halbach, O., 2013. Effects of the angiotensin-(1-7) receptor Mas on cell proliferation and on the population of doublecortin positive cells within the dentate gyrus and the piriform cortex. Eur Neuropsychopharmacol 24, 302308.

Gironacci, M.M., Longo Carbajosa, N.A., Goldstein, J., Cerrato, B.D., 2013. Neuromodulatory role of angiotensin-(1-7) in the central nervous system. Clin Sci (Lond) 125, 57-65. 
Goverman, J., Woods, A., Larson, L., Weiner, L.P., Hood, L., Zaller, D.M., 1993. Transgenic mice that express a myelin basic protein-specific $\mathrm{T}$ cell receptor develop spontaneous autoimmunity. Cell 72, 551-560.

Haider, L., Fischer, M.T., Frischer, J.M., Bauer, J., Hoftberger, R., Botond, G., Esterbauer, H., Binder, C.J., Witztum, J.L., Lassmann, H., 2011. Oxidative damage in multiple sclerosis lesions. Brain 134, 1914-1924.

Hammer, A., Yang, G., Friedrich, J., Kovacs, A., Lee, D.H., Grave, K., Jorg, S., Alenina, N., Grosch, J., Winkler, J., Gold, R., Bader, M., Manzel, A., Rump, L.C., Muller, D.N., Linker, R.A., Stegbauer, J., 2016. Role of the receptor Mas in macrophage-mediated inflammation in vivo. Proc Natl Acad Sci U S A 113, 14109-14114.

Hartung, H.P., Aktas, O., Boyko, A.N., 2015. Alemtuzumab: a new therapy for active relapsingremitting multiple sclerosis. Mult Scler 21, 22-34.

Hay, M., Vanderah, T.W., Samareh-Jahani, F., Constantopoulos, E., Uprety, A.R., Barnes, C.A., Konhilas, J., 2017. Cognitive impairment in heart failure: A protective role for angiotensin-(1-7). Behav Neurosci 131, 99-114.

Hoy, S.M., 2015. Peginterferon beta-1a: a review of its use in patients with relapsing-remitting multiple sclerosis. CNS Drugs 29, 171-179.

Jiang, T., Gao, L., Shi, J., Lu, J., Wang, Y., Zhang, Y., 2013. Angiotensin-(1-7) modulates reninangiotensin system associated with reducing oxidative stress and attenuating neuronal apoptosis in the brain of hypertensive rats. Pharmacol Res 67, 84-93.

Jiang, T., Yu, J.T., Zhu, X.C., Zhang, Q.Q., Tan, M.S., Cao, L., Wang, H.F., Lu, J., Gao, Q., Zhang, Y.D., Tan, L., 2014. Angiotensin-(1-7) induces cerebral ischaemic tolerance by promoting brain angiogenesis in a Mas/eNOS-dependent pathway. Br J Pharmacol 171, $4222-4232$.

Kawajiri, M., Mogi, M., Higaki, N., Matsuoka, T., Ohyagi, Y., Tsukuda, K., Kohara, K., Horiuchi, M., Miki, T., Kira, J.I., 2009. Angiotensin-converting enzyme (ACE) and ACE2 levels in the cerebrospinal fluid of patients with multiple sclerosis. Mult Scler 15, 262-265.

Kearney, H., Miller, D.H., Ciccarelli, O., 2015. Spinal cord MRI in multiple sclerosis-diagnostic, prognostic and clinical value. Nat Rev Neurol 11, 327-338. 
Khajah, M.A., Fateel, M.M., Ananthalakshmi, K.V., Luqmani, Y.A., 2017. Anti-inflammatory action of angiotensin 1-7 in experimental colitis may be mediated through modulation of serum cytokines/chemokines and immune cell functions. Dev Comp Immunol 74, 200208.

Kostenis, E., Milligan, G., Christopoulos, A., Sanchez-Ferrer, C.F., Heringer-Walther, S., Sexton, P.M., Gembardt, F., Kellett, E., Martini, L., Vanderheyden, P., Schultheiss, H.P., Walther, T., 2005. G-protein-coupled receptor Mas is a physiological antagonist of the angiotensin II type 1 receptor. Circulation 111, 1806-1813.

Kuchroo, V.K., Anderson, A.C., Waldner, H., Munder, M., Bettelli, E., Nicholson, L.B., 2002. T cell response in experimental autoimmune encephalomyelitis (EAE): role of self and cross-reactive antigens in shaping, tuning, and regulating the autopathogenic $\mathrm{T}$ cell repertoire. Annu Rev Immunol 20, 101-123.

Kumar, S., Patel, R., Moore, S., Crawford, D.K., Suwanna, N., Mangiardi, M., Tiwari-Woodruff, S.K., 2013. Estrogen receptor beta ligand therapy activates PI3K/Akt/mTOR signaling in oligodendrocytes and promotes remyelination in a mouse model of multiple sclerosis. Neurobiol Dis 56, 131-144.

Labandeira-Garcia, J.L., Garrido-Gil, P., Rodriguez-Pallares, J., Valenzuela, R., Borrajo, A., Rodriguez-Perez, A.I., 2014. Brain renin-angiotensin system and dopaminergic cell vulnerability. Frontiers in Neuroanatomy 8, 8.

Labandeira-Garcia, J.L., Rodriguez-Perez, A.I., Garrido-Gil, P., Rodriguez-Pallares, J., Lanciego, J.L., Guerra, M.J., 2017. Brain Renin-Angiotensin System and Microglial Polarization: Implications for Aging and Neurodegeneration. Front Aging Neurosci 9, 129.

Lanz, T.V., Ding, Z., Ho, P.P., Luo, J., Agrawal, A.N., Srinagesh, H., Axtell, R., Zhang, H., Platten, M., Wyss-Coray, T., Steinman, L., 2010. Angiotensin II sustains brain inflammation in mice via TGF-beta. J Clin Invest 120, 2782-2794.

Liu, J., Tian, D., Murugan, M., Eyo, U.B., Dreyfus, C.F., Wang, W., Wu, L.J., 2015. Microglial Hv1 proton channel promotes cuprizone-induced demyelination through oxidative damage. J Neurochem. 
Louie, K.A., Weiner, L.P., Du, J., Kochounian, H.H., Fling, S.P., Wei, W., McMillan, M., 2005. Cell-based gene therapy experiments in murine experimental autoimmune encephalomyelitis. Gene Ther 12, 1145-1153.

Lund, B.T., Ashikian, N., Ta, H.Q., Chakryan, Y., Manoukian, K., Groshen, S., Gilmore, W., Cheema, G.S., Stohl, W., Burnett, M.E., Ko, D., Kachuck, N.J., Weiner, L.P., 2004. Increased CXCL8 (IL-8) expression in Multiple Sclerosis. J Neuroimmunol 155, 161171.

Lund, B.T., Kelland, E.E., Hayardeny, L., Barilan, O., Gilmore, W., Weiner, L.P., 2013. Assessment of changes in immune measures of multiple sclerosis patients treated with laquinimod. J Neuroimmunol.

McCormack, P.L., 2013. Natalizumab: a review of its use in the management of relapsingremitting multiple sclerosis. Drugs 73, 1463-1481.

Mecca, A.P., Regenhardt, R.W., O'Connor, T.E., Joseph, J.P., Raizada, M.K., Katovich, M.J., Sumners, C., 2011. Cerebroprotection by angiotensin-(1-7) in endothelin-1-induced ischaemic stroke. Exp Physiol 96, 1084-1096.

Metzger, R., Bader, M., Ludwig, T., Berberich, C., Bunnemann, B., Ganten, D., 1995. Expression of the mouse and rat mas proto-oncogene in the brain and peripheral tissues. FEBS Lett 357, 27-32.

Mordwinkin, N.M., Meeks, C.J., Jadhav, S.S., Espinoza, T., Roda, N., diZerega, G.S., Louie, S.G., Rodgers, K.E., 2012. Angiotensin-(1-7) administration reduces oxidative stress in diabetic bone marrow. Endocrinology 153, 2189-2197.

Noseworthy, J.H., Lucchinetti, C., Rodriguez, M., Weinshenker, B.G., 2000. Multiple sclerosis. N Engl J Med 343, 938-952.

Oliveira-Lima, O.C., Pinto, M.C., Duchene, J., Qadri, F., Souza, L.L., Alenina, N., Bader, M., Santos, R.A., Carvalho-Tavares, J., 2015. Mas receptor deficiency exacerbates lipopolysaccharide-induced cerebral and systemic inflammation in mice. Immunobiology 220, 1311-1321.

Ozturk, A., Smith, S.A., Gordon-Lipkin, E.M., Harrison, D.M., Shiee, N., Pham, D.L., Caffo, B.S., Calabresi, P.A., Reich, D.S., 2010. MRI of the corpus callosum in multiple sclerosis: association with disability. Mult Scler 16, 166-177. 
Papinska, A.M., Mordwinkin, N.M., Meeks, C.J., Jadhav, S.S., Rodgers, K.E., 2015. Angiotensin-(1-7) administration benefits cardiac, renal and progenitor cell function in db/db mice. Br J Pharmacol 172, 4443-4453.

Papinska, A.M., Soto, M., Meeks, C.J., Rodgers, K.E., 2016. Long-term administration of angiotensin (1-7) prevents heart and lung dysfunction in a mouse model of type 2 diabetes $(\mathrm{db} / \mathrm{db})$ by reducing oxidative stress, inflammation and pathological remodeling. Pharmacol Res 107, 372-380.

Platten, M., Youssef, S., Hur, E.M., Ho, P.P., Han, M.H., Lanz, T.V., Phillips, L.K., Goldstein, M.J., Bhat, R., Raine, C.S., Sobel, R.A., Steinman, L., 2009. Blocking angiotensinconverting enzyme induces potent regulatory $\mathrm{T}$ cells and modulates TH1- and TH17mediated autoimmunity. Proc Natl Acad Sci U S A 106, 14948-14953.

Rabie, M.A., Abd El Fattah, M.A., Nassar, N.N., El-Abhar, H.S., Abdallah, D.M., 2018. Angiotensin 1-7 ameliorates 6-hydroxydopamine lesions in hemiparkinsonian rats through activation of MAS receptor/PI3K/Akt/BDNF pathway and inhibition of angiotensin II type-1 receptor/NF-kappaB axis. Biochem Pharmacol 151, 126-134.

Renno, W.M., Al-Banaw, A.G., George, P., Abu-Ghefreh, A.A., Akhtar, S., Benter, I.F., 2012. Angiotensin-(1-7) via the mas receptor alleviates the diabetes-induced decrease in GFAP and GAP-43 immunoreactivity with concomitant reduction in the COX-2 in hippocampal formation: an immunohistochemical study. Cell Mol Neurobiol 32, 1323-1336.

Rose, S., Misharin, A., Perlman, H., 2012. A novel Ly6C/Ly6G-based strategy to analyze the mouse splenic myeloid compartment. Cytometry A 81, 343-350.

Ruck, T., Bittner, S., Wiendl, H., Meuth, S.G., 2015. Alemtuzumab in Multiple Sclerosis: Mechanism of Action and Beyond. Int J Mol Sci 16, 16414-16439.

Sanford, M., 2014. Fingolimod: a review of its use in relapsing-remitting multiple sclerosis. Drugs 74, 1411-1433.

Santos, R.A., Campagnole-Santos, M.J., Andrade, S.P., 2000. Angiotensin-(1-7): an update. Regul Pept 91, 45-62.

Smith, K.J., 2011. Newly lesioned tissue in multiple sclerosis--a role for oxidative damage? Brain 134, 1877-1881.

Stegbauer, J., Lee, D.H., Seubert, S., Ellrichmann, G., Manzel, A., Kvakan, H., Muller, D.N., Gaupp, S., Rump, L.C., Gold, R., Linker, R.A., 2009. Role of the renin-angiotensin 
system in autoimmune inflammation of the central nervous system. Proc Natl Acad Sci U S A 106, 14942-14947.

Sumners, C., Horiuchi, M., Widdop, R.E., McCarthy, C., Unger, T., Steckelings, U.M., 2013. Protective arms of the renin-angiotensin-system in neurological disease. Clin Exp Pharmacol Physiol 40, 580-588.

Trapp, B.D., Nave, K.A., 2008. Multiple sclerosis: an immune or neurodegenerative disorder? Annu Rev Neurosci 31, 247-269.

Walther, T., Balschun, D., Voigt, J.P., Fink, H., Zuschratter, W., Birchmeier, C., Ganten, D., Bader, M., 1998. Sustained long term potentiation and anxiety in mice lacking the Mas protooncogene. J Biol Chem 273, 11867-11873.

Weiner, L.P., Louie, K.A., Atalla, L.R., Kochounian, H.H., Du, J., Wei, W., Hinton, D.R., Gordon, E.M., Anderson, W.F., McMillan, M., 2004. Gene therapy in a murine model for clinical application to multiple sclerosis. Ann Neurol 55, 390-399.

Xu, P., Sriramula, S., Lazartigues, E., 2011. ACE2/ANG-(1-7)/Mas pathway in the brain: the axis of good. Am J Physiol Regul Integr Comp Physiol 300, R804-817.

Zamvil, S.S., Steinman, L., 1990. The T lymphocyte in experimental allergic encephalomyelitis. Annu Rev Immunol 8, 579-621.

Zheng, J., Li, G., Chen, S., Bihl, J., Buck, J., Zhu, Y., Xia, H., Lazartigues, E., Chen, Y., Olson, J.E., 2014a. Activation of the ACE2/Ang-(1-7)/Mas pathway reduces oxygen-glucose deprivation-induced tissue swelling, ROS production, and cell death in mouse brain with angiotensin II overproduction. Neuroscience 273, 39-51.

Zheng, J.L., Li, G.Z., Chen, S.Z., Wang, J.J., Olson, J.E., Xia, H.J., Lazartigues, E., Zhu, Y.L., Chen, Y.F., 2014b. Angiotensin converting enzyme 2/Ang-(1-7)/mas axis protects brain from ischemic injury with a tendency of age-dependence. CNS Neurosci Ther 20, 452459.

\section{Figure legends:}

Figure 1. Therapeutic treatment with A(1-7) reduces clinical disease severity in MOG-EAE model. (A-D) Dose-response findings comparing saline BiD (closed circle) treated mice to mice treated with $0.5 \mathrm{mg} / \mathrm{kg} /$ day $\mathrm{BiD}$ (A; open circle), $1 \mathrm{mg} / \mathrm{kg} /$ day $\mathrm{BiD}$ (B; open square), $2 \mathrm{mg} / \mathrm{kg} /$ day 
$\mathrm{BiD}(\mathrm{C}$; open triangle) and 4mg/kg/day $\mathrm{BiD}$ (D; open diamond). Individual dose responses versus saline are plotted however, it should be noted that for this experiment all A(1-7) and saline treatments were run in parallel. Data are presented as mean clinical disease score (CDS) \pm S.E.M ( $\mathrm{n} \geq 8$ mice per treatment group) and experiment was repeated on two separate occasions. Treatment was initiated, on an individual mouse basis, at first clinical symptoms of disease (CDS $\geq 0.5$ ). Statistically significant differences were determined using repeated-measures one-way ANOVA with Dunnett's post-hoc test and is shown with adjoining line, where $* * *=p<0.001$. (E) Table showing the specific days post-immunization in which there was a statistically significant $(\mathrm{p}<0.05)$ difference between the mean CDS of saline versus $A(1-7)$ respective dose treated mice. Statistically significant differences were determined using student $t$ test analyses. (F) Changes in body weight of mice immunized with MOG peptide. Data are presented as mean weight (grams) \pm S.E.M. (G) Mean of cumulative CDS \pm S.E.M of saline (closed circle) or A(17) treated mice ( $\mathrm{n} \geq 8$ mice per treatment group). Statistically significant differences were determined by comparing the group mean saline $\mathrm{BiD}$ to the group mean $\mathrm{A}(1-7)$ for respective doses, using repeated-measures one-way ANOVA with Tukey's post-hoc test and is shown with adjoining line, where $* * *=\mathrm{p}<0.001$. BiD $=$ twice daily SQ injection.

Figure 2. Therapeutic treatment with $A(1-7)$ reduces clinical disease severity in MOG-EAE model. (A-D) Dose-response findings comparing saline MP (closed circle) treated mice to mice treated with $0.5 \mathrm{mg} / \mathrm{kg} /$ day MP (A; open circle), 1mg/kg/day MP (B; open square), 2mg/kg/day MP (C; open triangle) and 4mg/kg/day MP (D; open diamond). Individual dose responses versus saline are plotted however, it should be noted that for this experiment all A(1-7) and saline treatments were run in parallel. Data are presented as mean clinical disease score (CDS) \pm S.E.M ( $\mathrm{n} \geq 8$ mice per treatment group) and experiment was repeated on two separate occasions. Treatment was initiated, on an individual mouse basis, at first clinical symptoms of disease (CDS $\geq 0.5$ ). Statistically significant differences were determined using repeated-measures one-way ANOVA with Dunnett's post-hoc test and is shown with adjoining line, where $* * *=p<0.001$. (E) Table showing the specific days post-immunization in which there was a statistically significant $(\mathrm{p}<0.05)$ difference between the mean CDS of saline versus $A(1-7)$ respective dose treated mice. Statistically significant differences were determined using student $t$ test analyses. (F) Changes in body weight of mice immunized with MOG peptide. Data are presented as mean 
weight (grams) \pm S.E.M. Statistically significant differences were determined by comparing the group mean saline MP to the group mean A(1-7) for respective doses, using repeated-measures one-way ANOVA with Dunnett's post-hoc test and is shown with adjoining line, where $* * *=$ $\mathrm{p}<0.001$. (G) Mean of cumulative CDS \pm S.E.M of saline (closed circle) or $A(1-7)$ treated mice ( $\mathrm{n} \geq 8$ mice per treatment group). Statistically significant differences were by comparing the group mean saline MP to the group mean $\mathrm{A}(1-7)$ for respective doses using repeated-measures one-way ANOVA with Tukey's post-hoc test and is shown with adjoining line, where $* * *=$ $\mathrm{p}<0.001$. MP = osmotic minipump (SQ implant); continuous delivery.

Figure 3. Treatment with $\mathrm{A}(1-7)$ in MOG-EAE transgenic mice with Mas deletion failed to affect clinical disease course. MOG-EAE clinical disease course comparing 2mg/kg/day A(1-7) $\mathrm{BiD}$ treated Mas knockout (KO) mice (open triangles) to Mas KO mice treated with saline $\mathrm{BiD}$ (open squares) and wildtype C57BL/6N mice (closed circles). Data are presented as mean clinical disease score (CDS) \pm S.E.M ( $\mathrm{n}=5$ mice per treatment group). Treatment was initiated, on an individual mouse basis, at first clinical symptoms of disease (CDS $\geq 0.5$ ). Statistically significant differences were determined using repeated-measures one-way ANOVA with Dunnett's post-hoc test and Student's $t$ test.

Figure 4. Treatment with A(1-7) demonstrated reduced spinal cord lesion pathology in MOGEAE mice 40 days post-immunization. (A) Correlation of spinal cord scoring criteria and clinical disease score (CDS). Individual values for lesion score (x-axis) and corresponding CDS (y-axis) were plotted and the relative correlation between these values determined by calculating the correlation coefficient. (B-C) Semi-quantitative analysis of relative disease pathology (spinal cord score of myelin integrity and immune infiltration) in the spinal cord from mice receiving different doses of A(1-7) (white and shaded bars) or saline (solid bar). Data are presented as mean spinal cord score \pm S.E.M. assessed from serial spinal cord sections spanning the length of the cord ( 16 sections analyzed per mouse; $\mathrm{n}=4-6$ mice per group). Sections were stained with either solochrome cyanine or hematoxylin and eosin (H\&E), and a relative disease pathology score assigned. (D) Representative images of cross-sections of spinal cords stained with either solochrome cyanine (myelin, blue), H \& E (immune infiltration, purple) or Bielschowsky's silver (axons, brown/black) from mice with a CDS of 3.0 (upper row) and mice with a CDS of 1.0 
(lower row). E\&F) (i) Area of axon loss and (ii) Number of 3-nitrotyrosine positive cells in the dorsal column of spinal cord lumbar region of mice treated with $2 \mathrm{mg} / \mathrm{kg} \mathrm{A}(1-7) \mathrm{BiD}(\mathrm{E})$ or $1 \mathrm{mg} / \mathrm{kg} /$ day A(1-7) MP (F). For E\&F data presented as either mean area of axonal loss $\left(\mu \mathrm{m}^{2}\right)$ or mean number of 3-nitrotyrosine positive cells \pm S.E.M. Statistically significant differences were calculated by comparing the group mean saline ( $\mathrm{BiD}$ or $\mathrm{MP}$ ) to the group mean $\mathrm{A}(1-7)$ for respective dose, using either repeated-measures one-way ANOVA with Tukey's post-hoc test $(\mathrm{B} \& \mathrm{C})$ or Student's $t$-test $(\mathrm{E} \& \mathrm{~F})$, where $* * *=\mathrm{p}<0.001, * *=\mathrm{p}<0.001$ and $*=\mathrm{p}<0.05 . \quad \operatorname{BiD}=$ twice daily SQ injection. MP = continuous delivery by SQ implanted osmotic mini-pump.

Figure 5. Treatment with A(1-7) in MOG-EAE mice (40 days post-immunization) reduced PBMC proliferative responses to inoculating antigen. (A) The proliferative response of PBMC to inoculating antigen $\left(20 \mu \mathrm{g} / \mathrm{ml} \mathrm{MOG}_{35-55}\right)$ was assessed following treatment with $2 \mathrm{mg} / \mathrm{kg} / \mathrm{day}$ $\mathrm{BiD} \mathrm{A}(1-7)$ or saline BiD. (B) The proliferative response of PBMC to inoculating antigen (20 $\left.\mathrm{gg} / \mathrm{ml} \mathrm{MOG}_{35-55}\right)$ was assessed following treatment with $1 \mathrm{mg} / \mathrm{kg} / \mathrm{day} \mathrm{MP} \mathrm{A}(1-7)$ or saline MP. For both treatments, $2 \times 10^{6}$ PBMC were cultured with or without stimuli for 48hrs then pulsed with $0.2 \mu \mathrm{Ci}{ }^{3} \mathrm{H}$-thymidine for $18 \mathrm{hrs}$. ${ }^{3} \mathrm{H}$ incorporation was determined by scintillation counting and data calculated as stimulation index (fold increase in cpm incorporation with stimuli over background $\mathrm{cpm})$. Data are presented as mean stimulation index \pm S.E.M ( $\mathrm{n} \geq 4$ mice per treatment group). Statistically significant differences were calculated by comparing the group mean control (untreated non-EAE) to the group mean saline (BiD or MP) or $\mathrm{A}(1-7)(\mathrm{BiD}$ or MP) for respective dose or the group mean saline (BiD or MP) to the group mean $\mathrm{A}(1-7)$ for respective dose using the Student's t-test, $* *=\mathrm{p}<0.001$ and $*=\mathrm{p}<0.05$. $\mathrm{BiD}=$ twice daily SQ injection. $\mathrm{MP}=$ continuous delivery by SQ implanted osmotic mini-pump.

Figure 6. Treatment with A(1-7) increases splenocyte secretion of anti-inflammatory cytokines. The concentration of IL-2, IL-17A, IL-6, IFN $\gamma$, IL-4, IL-5, IL-13, TNF, MCP-1, MIG, RANTES and MIP-1a were measured in culture supernatants derived from MOG35-55-stimulated splenocytes collected at the end of the study (day 40). (A) show the relative secretion of solutes from non-immunized control mice (white bars), saline-treated EAE mice (black bars) and 2 $\mathrm{mg} / \mathrm{kg} /$ day BiD A(1-7) treated EAE mice (dark grey bars). (B) shows the relative secretion of solutes from non-immunized control mice (white bars), saline-treated EAE mice (black bars) and 
$1 \mathrm{mg} / \mathrm{kg} /$ day MP A(1-7) treated EAE mice (light grey bars). The concentration of antigenspecific secretion of solute by splenocytes was determined as the solute concentration in media alone subtracted from the solute concentration in presence of $\mathrm{MOG}_{35-55}$. Data are presented as mean concentration \pm S.E.M ( $\mathrm{n} \geq 4$ mice per treatment group). Statistically significant differences were calculated by comparing the group mean saline ( $\mathrm{BiD}$ or MP) to the group mean $\mathrm{A}(1-7)$ for respective dose using the Student's $t$-test, $* *=\mathrm{p}<0.001$ and $*=\mathrm{p}<0.05 . \mathrm{BiD}=$ twice daily SQ injection. $\mathrm{MP}=$ continuous delivery by SQ implanted osmotic mini-pump. Control splenocytes were from untreated non-immunized aged matched mice.

Figure 7. Treatment with $A(1-7)$ results in altered leukocyte populations. Splenocytes were assessed by FACS following (A) treatment with $2 \mathrm{mg} / \mathrm{kg} / \mathrm{day} \mathrm{BiD} \mathrm{A}(1-7)$ or saline $\mathrm{BiD}$ or (B) treatment with $1 \mathrm{mg} / \mathrm{kg} / \mathrm{day}$ MP $\mathrm{A}(1-7)$ or saline MP, to determine the proportion of $\mathrm{T}$ lymphocytes $\left(\mathrm{CD}^{2} 5^{\mathrm{hi}}, \mathrm{CD}^{+}, \mathrm{CD}^{+}{ }^{+}\right.$or $\left.\mathrm{CD}^{+}\right)$, monocytes and macrophages $\left(\mathrm{CD} 45^{\mathrm{hi}}, \mathrm{F} 4 / 80^{+}\right.$, $\left.\mathrm{CD} 1 \mathrm{~b}^{+}\right)$, dendritic cells $\left(\mathrm{CD} 45^{\mathrm{hi}}, \mathrm{CD} 11 \mathrm{c}^{+}, \mathrm{MHC}\right.$ class $\mathrm{II}^{\mathrm{hi}}$ ) and polymorphonuclear cells $\left(\mathrm{CD} 45^{\text {int }}, \mathrm{CD} 11 \mathrm{~b}^{+}, \mathrm{F} 4 / 80^{-}, \mathrm{Ly} \mathrm{G}^{+}\right)$. Data plotted are the percent of total $\mathrm{CD}^{+} 5^{+}$splenocytes expressing the markers of interest for each sample \pm S.E.M ( $\mathrm{n} \geq 4$ mice per treatment group). Statistically significant differences were calculated by comparing the group mean saline (BiD or $\mathrm{MP})$ to the group mean $\mathrm{A}(1-7)$ for respective dose using the Student's $t$-test, $*=\mathrm{p}<0.05 . \quad \mathrm{BiD}=$ twice daily SQ injection. MP = continuous delivery by SQ implanted osmotic mini-pump.

Figure 8. Treatment with $\mathrm{A}(1-7)$ in MOG-EAE mice increases the relative proportion of $\mathrm{CD}_{11 \mathrm{~b}^{+}}$monocytes expressing Ly6C $\mathrm{C}^{\mathrm{lo} / \mathrm{neg}}$. (A) Splenocytes collected at the end of the study were assessed by FACS following (i) treatment with $2 \mathrm{mg} / \mathrm{kg} / \mathrm{day} \mathrm{BiD} \mathrm{A}(1-7)$ or saline $\mathrm{BiD}$ or (ii) treatment with $1 \mathrm{mg} / \mathrm{kg} / \mathrm{day}$ MP A(1-7) or saline MP. The proportion of $\mathrm{CD} 11 \mathrm{~b}^{+}$monocytes expressing CCR2 ${ }^{+}$and Ly6C ${ }^{\text {hi }}$ (classically activate) versus those cells that were CCR2 ${ }^{\text {neg }}$ and Ly6C ${ }^{\text {lo/neg }}$ (alternatively activated) was determined. Data were calculated as mean percent of total PBMC expressing the markers of interest \pm S.E.M ( $\mathrm{n} \geq 4$ mice per treatment group). (B) The concentration of IL-6 and IL-10 were measured in culture supernatants derived from LPS \& IFN $\gamma$ stimulated $\mathrm{CD} 11 \mathrm{~b}^{+}$monocytes following treatment with $1 \mathrm{mg} / \mathrm{kg} /$ day MP A(1-7) (light gray bar), 2mg/kg/day BiD A(1-7) (dark gray bar), saline (black bar) or non-immunized mice (white bar). Solute concentration was determined as the stimulant-specific portion only (solute 
concentration in media alone subtracted from the solute concentration in presence of LPS \& IFN $\gamma$ ). Data are presented as mean concentration \pm S.E.M ( $\mathrm{n} \geq 4$ mice per treatment group). Statistically significant differences were calculated by comparing the group mean saline or control to the group mean $\mathrm{A}(1-7)$ (MP or $\mathrm{BiD}$ ) using the Student's $t$-test. $\mathrm{BiD}=$ twice daily SQ injection. $\mathrm{MP}=$ continuous delivery by SQ implanted osmotic mini-pump. 